\title{
STUDY OF SOME TESTICULAR DIMENSIONS AND THEIR RELATIONSHIP TO BODY WEIGHT IN KARADI RAM LAMBS
}

\author{
CHOWMAN ALADDIN OMAR \\ Ph.D., Faculty of Agricultural Sciences, Sulaimani University, Bakrajo Street, Sulaimaniah-Iraq.
}

Received: 3 May 2016; $\quad$ Accepted: 15 June 2016

\begin{abstract}
This study was carried out to measure the development of some testicular traits and to investigate the relevance between testicular parameters with body growth in growing Karadi ram lambs. Twenty-seven single born Karadi ram lambs apparently clinical healthy, aged six months, were used. The Testicular measurements including: length, diameter, and circumference of their testes and body weight were recorded once monthly. The testicular measurement $(\mathrm{cm})$ and body weight $(\mathrm{kg})$ were subjected to linear $(\mathrm{Y}=\mathrm{a}+\mathrm{bX})$ where, $\mathrm{Y}$ means the testicular measurement and $\mathrm{X}$ is the body weight, $\mathrm{a}$ and $\mathrm{b}$ are constants due to the intercept and the regression coefficient, respectively. The results revealed that there was a gradual and linear increase in testicular dimensions from six to eight months of age. The average scrotal circumference $(\mathrm{SC})$ showed significant $(\mathrm{P} \leq 0.05)$ increase from $10.66 \pm 0.74$ to $17.88 \pm 1.19 \mathrm{~cm}$ at 6 and eight months of age, respectively. Corresponding changes in the average testicular volume were found to be $14.31 \pm 3.66,77.66 \pm 23.54$ and $104.23 \pm 23.92 \mathrm{~cm}^{3}$ at 6,7 and eight months of age, respectively. All measurements of testis, live weight, were positively and significantly correlated with each other. While a significant positive correlation were found at seven and eight months of age between all testicular measurements. These results showed that testicular measurements, such us scrotal circumference, can be used as criteria for early selection of ram lambs to be utilize in breeding especially for young ages. Due to the strong correlation between body weight and testicular measurements, body measurements can be used to select Karadi ram lambs for breeding programs. However, further studies are needed to determine the relationship between these subjective morphological criteria and the actual fertility and semen quality in Karadi rams.
\end{abstract}

Key Words: Karadi ram lambs; testicular development; body weight; scrotal circumference.

\section{INTRODUCTION}

Agricultural traits, economic Natural and conditions, pasture areas and traditions create suitable conditions for sheep breeding in Iraq. Karadi is the main native sheep breed of Kurdistan region. Average adult body weight of Karadi ram were 50 $\mathrm{Kg}$ while for ewe were $42 \mathrm{~kg}$ (Al-Jalili et al., 1988). It has the thick tail and short ears and produces meat, wool and milk. Most of the lambs are early weaned at one and a half months of age, therefore ewes can be milked longer and the majority of the lambs are slaughtered without further fattening. In this way, meat production potential of these lambs is poorly utilized. Karadi meat quality is considered to be the best among local and imported breeds as it has a good marbling.

In sheep breeding, reproductive performance is the most important factor in correlation with increasing

Corresponding author: Dr. CHOWMAN ALADDIN OMAR E-mail address: choman.omer@univsul.edu.iq

Present address: Ph.D., Faculty of Agricultural Sciences, Sulaimani University, Bakrajo Street, Sulaimaniah-Iraq. profitability (Bilgin et al., 2004). Knowing of the parameters relating to ram testicles property provides valuable information for both lamb productivity with indirect selection in breeding and sperm production, the direction of new possibilities in the selection of Rams. Therefore, parameters such as testicular measurments are very important (Kaymakçı et al., 1988). Selection for fertility in sheep can be accomplished through selecting for correlated characters in young rams such as testis size (Land and Carr, 1975). When observing testis growth, and small but convenient differences in the development of sexual activity and sperm production, young rams of prolific breeds (Romanov and Finnish Landrace) might differ in their potential reproductive performance, though slightly was suggested previously by (Louda et al., 1981).

Scrotal and testicular measurments like testicular length, testicular diameter, scrotal length, and scrotal circumference have been utilized as indirect selection criteria to improve fertility (Öztürk et al., 1996). The testicular traits that can be easily measured in early stages of growth periods are vital characteristics with high heritability (Rege et al., 2000; Bilgin et al., 
2004) and have highly correlations with one another (Salhab et al., 2001). There are significant factors (genotype, rearing systems, season, age, body weight, etc.) influencing the development of testicular characteristics (Ley et al., 1990; Aral and Tekin, 1996; Aygün et al., 1999 and Gündoğan et al., 2002). Many workers showed that, within factors, age and body weight had the significant impact on testicular traits (Salhab et al., 2001; Özdemir and Altın, 2002; Yılmaz and Aygün, 2002). Thus, there were few studies on the comparison of non-linear models on a development of some testicular characteristics in sheep (Bilgin et al., 2004) and bulls (Terawaki et al., 1994 and Quirino et al., 1999).

Testicular growth and development related closely to body size and they confirmed that males with higher values of testicular parameters had maximum body weight. General, sexual development of ram lamb occur to be more closely related to body growth than to chronological age (Dyrmundsson and Lees, 1972). It was expected that, the various measurements of testes were related positively and significantly $(\mathrm{P} \leq 0.01)$ with each other. All listed characteristics confirm the presence of linear relationships between testicular, body weight, and scrotal measurements when age is taken as constant $(\mathrm{P} \leq 0.01)$. Similarly, Kritzinger et al. (1984), Zeng and Lu (1987), Öztürk et al. (1996) and Salhab et al. (2001) reported high significant correlations between testis parameters and body weight. Testicular and scrotal parameters were positively correlated with each other. The estimation of testis length was useful of testicular growth since its correlations were the highest with the other testicular measurements. Moreover, the testes measurements showed a positive relationship with body weight and age of ram lambs.

The results of these studies lead to postulate that the measurements of testicular and scrotal criteria were suitable for early selection of the ram lambs. On the other hand, the selection of ram lambs based on scrotal and testicular measurements are not sufficient. Furthermore, the differences among all the studies in the literature may be due to breed, age, season, and feeding strategies and other environmental/ management practices.

Therefore, the purpose of this investigation was to measure the development of several testicular characteristics, factors affecting them, and the relationship of testicular parameters to body growth in growing ram lambs.

\section{MATERIALS AND METHODS}

The study was carried out at the Research Farm of Agricultural Sciences Faculty of Sulaimani University in Bakrajo (Latitude: 35³3'11" N; Longitude: $45^{\circ} 21^{\prime} 14^{\prime \prime}$ E; 760 masl). Twenty seven
(27) Karadi ram lambs with 6 months old were used in this experiment. The animals were apparently healthy and raised under the same management and nutrition conditions. Lambs will receive $(3 \% \mathrm{BW})$ of concentrates, water and hay were provided ad libitum. All data were recorded from November $1^{\text {st }}$, 2014 to January $8^{\text {th }}, 2015$.

For all animals, these parameters, testicular length, diameter and the circumference of testis, scrotum length, scrotum volume and body weights, were measured monthly at the ages of 6,7 and 8 months. Testis measurements were obtained via a technique reported by Sönmez and Kaymakci (1987). Briefly, ram lambs were held in a position in which forelegs were up. The length and diameter of testes will be measured with a caliper. The scrotal circumference and length were measured by a flexible cloth tape. Scrotal circumference (SC) and testis diameter (TD) were obtained with a cloth tape. It was measured in centimeters $(\mathrm{cm})$ as the largest diameter of the testes and scrotum after pushing the testes firmly into the scrotum. The scrotal length was measured with a vernier caliper as the distance between the tip of the scrotal sack and its neck.

The volume of the testis was estimated as reported by Godfrey et al. (1998):

Testes volume $\left(\mathrm{cm}^{3}\right)=0.0396 \times$ (average testis length) $\mathrm{x}$ (scrotal circumference $)^{2}$.

Statistical analyzes of all data conducted by using the (XLSTAT, 2015) program v. 20.1 for Windows (Addinsoft, 1995-2015). One-way ANOVA was used for repeated measurements. Duncan's test were used to comparison between the means. Correlations between measurements were obtained using the Spearman Correlation Test. Sources of variation as: ram ages, the age of lamb and weight at each measurement were the factors included in the model. Coefficients of correlation and determination between testicular measurements and body weight were estimated. Regression equations between the above factors were calculated (Düzgüneş et al., 1983).

The model used for statistical analysis was as follows:

$$
Y i j k l=\mu+a i+c j+b X i j k l+e i j k l
$$

where: $\mu=$ the overall mean

ai $=$ the effect of ith age $(i=6,7,8)$

$\mathrm{cj}=$ the effect of $\mathrm{jth}$ replicat $(\mathrm{j}=2,3,4$, ......, 27)

$\mathrm{b}=$ the partial regression coefficient of testis or scrotum measure on live weight.

$\mathrm{Xijkl}=$ the live weight at each measurement eijkl $=$ the random error. 
Regression equations between testicular and scrotal measurements, age and body weight together with estimates of coefficients of determination are Studied. Regression equations between the above factors were calculated (Düzgüneş et al., 1983). The statistical model used in the analysis was as follows:

$$
\begin{aligned}
& \mathbf{Y}=\mathbf{a}+\mathbf{b X} \\
& \mathbf{Y}=\mathbf{b 0}+\mathbf{b} 1 \ln (\mathbf{X}) \\
& \text { where: } \\
& Y \quad=\text { Testicular measurement } \\
& \mathrm{X} \quad=\text { Body weight }
\end{aligned}
$$

$\mathrm{a}$ and $\mathrm{b}=$ Constants denoting the intercept and the regression coefficient, respectively.

\section{RESULTS}

The relationship between body weight and testicular measurement in local ram lambs was investigated in this study. As shown in Table 1, the ram lambs were still growing, and their average live body weights increased from $21.82 \pm 1.18 \mathrm{~kg}$ at six months of age to reach $24.556 \pm 1.53 \mathrm{~kg}$ by eight months of age.

The scrotal circumference (SC) was found significant $(\mathrm{P} \leq 0.05)$ increase from $10.66 \pm 0.74$ to $17.88 \pm 1.19 \mathrm{~cm}$ at 6 and eight months of age, respectively. Corresponding changes in the average testicular

\begin{tabular}{|c|c|c|c|}
\hline \multirow{2}{*}{ Trait* } & \multicolumn{3}{|c|}{ Age (month) } \\
\hline & 6 & 7 & 8 \\
\hline$B W(k g)$ & $21.82 \pm 1.18^{\mathrm{a}}$ & $23.82 \pm 1.25^{\mathrm{a}}$ & $24.556 \pm 1.53^{\mathrm{a}}$ \\
\hline$S L(\mathrm{~cm})$ & $5.222 \pm 0.371^{\mathrm{c}}$ & $7.778 \pm 0.8121^{b}$ & $9.444 \pm 0.489^{a}$ \\
\hline$S W(\mathrm{~cm})$ & $3.444 \pm 0.395^{\mathrm{b}}$ & $6.056 \pm 0.417^{\mathrm{a}}$ & $7.000 \pm 0.433^{\mathrm{a}}$ \\
\hline$S H(\mathrm{~cm})$ & $1.444 \pm 0.206^{\mathrm{b}}$ & $3.111 \pm 0.340^{\mathrm{a}}$ & $3.167 \pm 0.337^{\mathrm{a}}$ \\
\hline$S C(\mathrm{~cm})$ & $10.66 \pm 0.74^{\mathrm{b}}$ & $16.16 \pm 1.50^{\mathrm{a}}$ & $17.88 \pm 1.19^{\mathrm{a}}$ \\
\hline$T L(\mathrm{~cm})$ & $2.889 \pm 0.274^{\mathrm{b}}$ & $6.389 \pm 0.668^{\mathrm{a}}$ & $7.500 \pm 0.620^{\mathrm{a}}$ \\
\hline$T W(\mathrm{~cm})$ & $1.222 \pm 0.134^{\mathrm{b}}$ & $3.000 \pm 0.320^{\mathrm{a}}$ & $3.389 \pm 0.375^{\mathrm{a}}$ \\
\hline$T H(\mathrm{~cm})$ & $1.056 \pm 0.063^{b}$ & $2.333 \pm 0.245^{\mathrm{a}}$ & $2.611 \pm 0.263^{\mathrm{a}}$ \\
\hline$T V\left(\mathrm{~cm}^{3}\right)$ & $14.31 \pm 3.66^{\mathrm{b}}$ & $77.66 \pm 23.54^{\mathrm{a}}$ & $104.23 \pm 23.92^{\mathrm{a}}$ \\
\hline
\end{tabular}
volume were found $(\mathrm{P} \leq 0.05)$ to be $14.31 \pm 3.66$, $77.66 \pm 23.54$ and $104.23 \pm 23.92 \mathrm{~cm}^{3}$ at 6,7 and eight months of age, respectively.

Table 1: The mean $( \pm \mathrm{SE})$ of Body weight and testicular measurements in Karadi ram lambs.

*BW= Body weight, $\mathrm{SL}=$ Scrotum Length, $\mathrm{SW}=$ Scrotum Width, $\mathrm{SH}=$ Scrotum Height, $\mathrm{SC}=\mathrm{Scrotum}$ Circumference, TL= Testicular Length, $\mathrm{TW}=$ Testicular Width, $\mathrm{TH}=$ Testicular Height, $\mathrm{TV}=$ Testicular Volume.

$* *$ Values (mean $\pm \mathrm{SE}$ ) in the same row with different superscripts differ significantly at $\mathrm{P} \leq 0.05$.

Table 2, 3, 4 were shown the correlations between the testicular and scrotal measurements and body weight. The body weight $\mathrm{BW}$ were not correlated positively $(\mathrm{P}>0.01)$ with all testicular measurements at age six months (Table 2). Conversely, they were significant $(\mathrm{P} \leq 0.05)$ correlation between $\mathrm{BW}$ and $\mathrm{SL}$,
SH, TL, TW, and TH at age seven months of age (Table 3), which were $0.882,0.727,0.713,0.788$ and 0.728 , respectively. At age eight months, the BW a strong and positive correlated with SL, TL, TW, and TV $(0.863,0.886,0.866$ and 0.883 , respectively). 
Table 2: The Correlation Coefficient between live body weight and Testicular measurements of Karadi ram lambs at age (6 months).

\begin{tabular}{|c|c|c|c|c|c|c|c|c|c|}
\hline Measurements & BW & SL & SW & SH & SC & TL & TW & TH & TV \\
\hline Body Weight $(B W)$ & 1 & & & & & & & & \\
\hline Scrotum Length (SL) & 0.222 & 1 & & & & & & & \\
\hline Scrotum Width (SW) & 0.460 & 0.633 & 1 & & & & & & \\
\hline Scrotum Height (SH) & 0.330 & 0.522 & 0.619 & 1 & & & & & \\
\hline $\begin{array}{c}\text { Scrotum Circumference } \\
(S C)\end{array}$ & 0.426 & $0.838^{* * *}$ & $0.835^{* *}$ & 0.731* & 1 & & & & \\
\hline Testicular Length (TL) & 0.691 & 0.399 & 0.295 & 0.505 & 0.531 & 1 & & & \\
\hline Testicular Width (TW) & 0.647 & 0.148 & 0.448 & 0.790* & 0.488 & 0.585 & 1 & & \\
\hline Testicular Height (TH) & 0.411 & 0.492 & 0.560 & 0.603 & 0.560 & 0.575 & 0.655 & 1 & \\
\hline Testicular Volume (TV) & 0.544 & $0.811 *$ & $0.722 *$ & 0.663 & $0.949 * *$ & 0.650 & 0.520 & 0.550 & 1 \\
\hline
\end{tabular}

$* \mathrm{P} \leq 0.05 ; * * \mathbf{P} \leq 0.01$.

Table 3: The Correlation Coefficient between live body weight and Scrotum measurements of Karadi ram lambs at age ( 7 months).

\begin{tabular}{|c|c|c|c|c|c|c|c|c|c|}
\hline Measurements & BW & SL & SW & SH & SC & TL & TW & TH & TV \\
\hline Body Weight (BW) & 1 & & & & & & & & \\
\hline Scrotum Length (SL) & $0.882 * *$ & 1 & & & & & & & \\
\hline Scrotum Width $(S W)$ & 0.664 & $0.834 * *$ & 1 & & & & & & \\
\hline Scrotum Height (SH) & $0.727 *$ & $0.880 * *$ & $0.916 * *$ & 1 & & & & & \\
\hline $\begin{array}{c}\text { Scrotum Circumference } \\
(S C)\end{array}$ & 0.647 & $0.814 *$ & $0.944 * *$ & $0.812 *$ & 1 & & & & \\
\hline Testicular Length (TL) & 0.713* & $0.915 * *$ & $0.851 * *$ & $0.863 * *$ & $0.865 * *$ & 1 & & & \\
\hline Testicular Width (TW) & 0.788* & $0.894 * *$ & $0.904 * *$ & $0.974 * *$ & $0.814 *$ & $0.809 *$ & 1 & & \\
\hline Testicular Height (TH) & $0.728 *$ & $0.916 * *$ & $0.848 * *$ & $0.928 * *$ & $0.820 *$ & $0.888 * *$ & $0.892 * *$ & 1 & \\
\hline Testicular Volume (TV) & 0.686 & $0.882 * *$ & $0.940 * *$ & $0.877 * *$ & $0.979 * *$ & $0.933 * *$ & $0.869 * *$ & $0.881 * *$ & 1 \\
\hline
\end{tabular}

$* \mathrm{P} \leq 0.05 ; * * \mathrm{P} \leq 0.01$. 
Table 4: The Correlation Coefficient between live body weight and Scrotum measurements of Karadi ram lambs at age (8 months).

\begin{tabular}{|c|c|c|c|c|c|c|c|c|c|}
\hline Measurements & BW & SL & SW & SH & SC & TL & TW & TH & TV \\
\hline Body Weight(BW) & 1 & & & & & & & & \\
\hline Scrotum Length (SL) & 0.608 & 1 & & & & & & & \\
\hline Scrotum Width $(S W)$ & $0.863 * *$ & $0.760 *$ & 1 & & & & & & \\
\hline Scrotum Height (SH) & 0.417 & $0.806 *$ & 0.634 & 1 & & & & & \\
\hline $\begin{array}{l}\text { Scrotum Circumference } \\
(S C)\end{array}$ & $0.782 *$ & $0.902 * *$ & $0.939 * *$ & $0.768 *$ & 1 & & & & \\
\hline Testicular Length (TL) & $0.886 * *$ & $0.756 *$ & $0.970 * *$ & 0.595 & $0.945 * *$ & 1 & & & \\
\hline Testicular Width (TW) & $0.866 * *$ & 0.638 & $0.974 * *$ & 0.601 & $0.886 * *$ & $0.957 * *$ & 1 & & \\
\hline Testicular Height (TH) & 0.567 & 0.660 & $0.844 * *$ & $0.802 *$ & $0.791 *$ & $0.754 *$ & $0.854 * *$ & 1 & \\
\hline Testicular Volume (TV) & $0.883 * *$ & $0.810 *$ & $0.966 * *$ & 0.655 & $0.975 * *$ & $0.987 * *$ & $0.941 * *$ & $0.754 *$ & 1 \\
\hline
\end{tabular}

$* \mathbf{P} \leq \mathbf{0 . 0 5} ; * \mathbf{P} \leq \mathbf{0 . 0 1}$

There was a strong and positive correlation between body weight and testicular measurements in Karadi ram lambs. In the present study linear regression coefficient for the scrotal and testicular measurements on body weight $\mathrm{BW}$, were 0.432 , $0.501,0.463$ and 0.563 for SL, SW, SH, and SC, respectively (Table 5). Testicular regression coefficients were $0.518,0.547,0.457$ and 0.642 for TL, TW, TH and TV, respectively. This indicates that for each unit increaseing in body weight there was a 0.909 in the scrotum circumference (SC) and at the same time, there were 13.82 unit increases in the testicular volume (TV) (Table 5).

Table 5: Simple regression equation and coefficient of determination $\left(\mathrm{R}^{2}\right)$ of testicular measurements on body weight in Karadi ram lambs.

\begin{tabular}{cccc} 
Testicular measurement & Regression equation $(\mathbf{Y}=\mathbf{a}+\mathbf{b x})$ & $\mathbf{R}^{2}$ & p-values \\
\hline$S L(\mathrm{~cm})$ & $\mathrm{SL}=2.387+0.421 * \mathrm{BW}$ & $0.432^{* *}$ & $<0.0001$ \\
$S W(\mathrm{~cm})$ & $\mathrm{SW}=2.950+0.361 * \mathrm{BW}$ & $0.501 * *$ & $<0.0001$ \\
$S H(\mathrm{~cm})$ & $\mathrm{SH}=2.372+0.211 * \mathrm{BW}$ & $0.463^{* *}$ & $<0.0001$ \\
$S C(\mathrm{~cm})$ & $\mathrm{SC}=6.367+0.909 * \mathrm{BW}$ & $0.578^{* *}$ & $<0.0001$ \\
$T L(\mathrm{~cm})$ & $\mathrm{TL}=5.728+0.483 * \mathrm{BW}$ & $0.518^{* *}$ & $<0.0001$ \\
$T W(\mathrm{~cm})$ & $\mathrm{TW}=3.272+0.248 * \mathrm{BW}$ & $0.547^{* *}$ & $<0.0001$ \\
$T H(\mathrm{~cm})$ & $\mathrm{TH}=1.805+0.162 * \mathrm{BW}$ & $0.457^{* *}$ & $<0.0001$ \\
$T V(\mathrm{~cm})$ & $\mathrm{TV}=258.10+13.82 * \mathrm{BW}$ & $0.642^{3} * *$ & $<0.0001$ \\
\hline
\end{tabular}

$\mathrm{BW}=$ Body weight, $\mathrm{SL}=$ Scrotum Length, $\mathrm{SW}=$ Scrotum Width, $\mathrm{SH}=$ Scrotum Height, $\mathrm{SC}=$ Scrotum Circumference, $\mathrm{TL}=$ Testicular Length, TW= Testicular Width, TH= Testicular Height, $\mathrm{TV}=$ Testicular Volume.

$* * \mathbf{P} \leq \mathbf{0 . 0 1}$ 


\section{DISCUSSION}

In the present study, the average of all testicular circumference measurements in local Karadi rams increased significantly from 6 months to reach eight months of age (Table 1). Testicular development in young rams was found more closely associated with body weight than with its age, these results agree with Matos et al. (1992). The changes that occur during growth of the testis from birth to sexual maturity and testicular measurements have been well documented for Rams (Dyce et al., 2002). In many studies, testicular measurements have been evaluated and related to some seminal parameters usually sperm concentration and sperm motility. It has been suggested that young ram to be used for breeding should have scrotal circumference $>30 \mathrm{~cm}$ that reported by Master (1988), which were agreed with the present study. Hafez et al. (1955) reported that testis size is important because of its high correlation with sperm production potential and it is a highly heritable trait that could easily be improved by selection.

The logarithmic regression coefficient is the percentage increase of the dependent variable in each $1 \%$ increase of the independent variable. This regression coefficient (b) were used by Gaili and Nour (1980) to relate the growth of each wholesale cut to whole carcass growth, which was stated that when the value of $b$ is $<1$, the organ or tissue grows at a lower rate than the whole body weight does, but when the value of $b$ is $>1$ then the organ or tissue grows at a higher rate than the whole body weight does, and also mention that the difference in growth is significant if the error of $b$ is less than the difference between $b$ and 1 . The estimation of testis length in recent experiment was useful for testicular growth via correlations in compared to other testicular measurements. This result in agreement with the results of Land and Carr (1975), KumiDiaha et al. (1985), Kaymakci et al. (1988), Foster et al. (1989), Koyuncu et al. (2000) and Salhab et al. (2001). Regression equations presented in Table (5) describe the relationship between testicular and scrotal dimensions $(\mathrm{cm})$ or volume $\left(\mathrm{cm}^{3}\right)$ and the body weight $(\mathrm{kg})$ of ram lambs, which were revealed that testes measurements showed a positive relationship with body weight and age of ram lambs. These results are close to the findings of Kaymakci et al. (1988), Mukasa-Mugerva and Ezaz (1992), Koyuncu et al. (2000) and Salhab et al. (2001).

\section{CONCLUSION}

The results of this study lead us to postulate that the suitability of testicular and scrotal measurements as criteria for early selection of ram lambs was emphasized. There was a strong and positive correlation testicular measurements and body weight in Karadi ram lambs. Due to unavailability of directly, measurable traits for selecting males with superior fertility, body measurements can be used for selection of sire rams.

On the other hand, the selection of breeding rams based only on scrotal and testicular measurements is not sufficient. However, further studies are needed to determine the relationships between these morphological criteria and the actual fertility semen quality in Karadi rams. Moreover, we needed further studies on spermatogenetic activity and testosterone hormone to confirm the present results. The ultimate aim would be to find objective selection criteria for ram fertility.

\section{ACKNOWLEDGMENT}

The authors are sincerely thankful for the animal farm research station of the Faculty of Agricultural Sciences / University of Sulaimani at Bakrajo for the financial and technical support of this research project.

\section{REFERENCES}

Al-Jalili, Z.F.; Alwan, M.T. and Hussein, S.H. (1988): "Effect of breed, age of dam and sex of lamb on pre-weaning weight of lamb". Iraqi journal of Veterinary Medecine, 12, pp.39-35.

Aral, F. and Tekin, N. (1996): "The effect of season on sperm quality in rams". J. of Anim. Prod., 6(1-2), pp. 15-20.

Aygün, T.; Karaca, O.; Altın, T.; Demirel, M. and Bingöl, M. (1999): "Testis Development in Karakaş and Karakaş x Hamdani (G1) crossbred ram- lambs Raised under different fattening and feeding conditions". University of Yüzüncü Yil, J Agric. Sci., 6 (1), pp. 53-60.

Bilgin, O.C.; Emsen, E. and Davis, M.H. (2004): "Comparison of non-linear models for describing the growth of scrotal circumference in Awassi male lambs". Small Rum. Res., 52, pp. 155-160.

Düzgüneş, O.; Kesici, T. and Gürbüz, F. (1983): "İstatistik Metodları I.A". Ü. Zir. Fak. Yay. No. 861.

Dyce, K.M.; Sack, W.O. and Wesing, G.J.G. (2002): "The pelvic and reproductive organs of male ruminants". In text book of veterinary, anatomy, pp. 713-722.

Dyrmundsson, O.R. and Lees, J.L. (1972): "Puberal development of Clun Forest ram lambs in relation to time of birth". J. Agr. Sci. (Camb), 79, pp. 83-89.

Foster, R.A.; Ladds, P.W.; Hoffmann, D. and Briggs, G.D. (1989): "The relationship of scrotal circumference to testicular weight in rams". Aust. Vet. J., 66, pp. 20-22. 
Gaili, E.S.E. and Nour, A.F.Y.M. (1980): "Development of body component in kenana cattle. 1. Development of carcass and noncarcass components of the body". J. Agric. Sci., 94, pp. 257-262.

Godfrey, R.W.; Collins, J.R. and Gray, M.L. (1998): "Evaluation of sexual behavior of hair sheep rams in a tropical environment". J. Anim. Sci. 76, pp. 714-717.

Gündoğan, M.; Uçar, M. and Tekerli, M. (2002): "Investigations on morphometrical and spermatological traits of testes of rams raised under Afyon condition". J Vet. Sci., 18(1-2), pp. 63- 67.

Hafez, E.S.E.; Endorin, A.L. and Darwish, V.H. (1955): "Seasonal Variation in semen characteristics in the subtropics". J. Agric. Sci., 94, pp. 257-262.

Kaymakçı, M.; Sarıcan, C. and Karaca, O. (1988): "Investigations on the testis characteristics in Acipayam male lambs". Ege University, J. Agric. Faculty., 25 (2), pp. 109-123.

Koyuncu, M.; Şengül, L. and Tuncel, E. (2000): "Karayaka toklularında bazı testis özellikleri". Hayvansal Üretim, 41, pp. 102-107.

Kritzinger, N.M.; Stindt, H.W. and Westhuysen, J.M. (1984): "Assessment of different selection criteria for reproduction rate in Dormer and SA Mutton Merino sheep. 3. Prepubertal testis size of ram lambs". S. Afr. J. Anim. Sci., 14, pp. 88-90.

Kumi-Diaka, J.A.; Adesiyum, A.A.; Sekoni, V. and Ezeokoli, C.D. (1985): "Scrotal dimensions and ejaculate characteristics of three breeds of sheep in Tropical Nigeria". Theriogenology, 23, pp. 671-677.

Land, R.B. and Carr, W.R. (1975): "Tests growth and plasma LH concentration following hemicastration and its relation with female prolificacy in sheep". J. Rep. Fertil., 45, pp. 495.

Ley, W.B.; Sprecher, D.J.; Thatcher, L.P.; Pelzer, K.D. and Umberger, S.H. (1990): "Scrotal Circumference Measurements in Purebreed Dorset, Hampshire and Suffolk Lamb and Yearling Rams". Theriogenology, 34 (4), pp. 734- 747.

Louda, F.; Donery, J.M.; Štolc, L.; Křžžek, J. and Šmerda, J. (1981): "The development of sexual activity and semen production in ram lambs of two prolific breeds, Romanov and Finnish Landrace”. Anim. Prod., 33, pp. 143148.

Master, J.C. (1988): “Testis size. Why is normal?". Dohne Merino J., 12, pp. 55-57.

Matos, C.A.P.; Thomas, D.L.; Nash, T.C.; Waldron, D.F. and Stooky, J.M. (1992): "Genetic analyses of scrotal circumference, size and growth in ram bouillet lambs". J. Anim. Sci., 70, pp. 43-50.

Mukasa-Mugerva, E. and Ezaz, Z. (1992): "Relationship of testicular growth and size to age, body weight and onset of puberty in Menz ram lambs". Theriogenology, 38, pp. 979-988.

Özdemir, Z. and Altın, T. (2002): "Testis characteristics in Norduz Male Lambs". University of Yüzüncü Yil, J Agric. Sci., 12(1), pp. 13-20.

Öztürk, A.; Dăg, B. and Zülkadir, U. (1996): "Akkaraman ve İvesi koçların bazı testis özelliklerinin döl verimine etkisi”. Türk Veterinerlik ve Hayvancılık Dergisi, 20, pp. 127-130.

Quirino, C.R.; Bergmann, J.A.G.; Vale, F.V.R.; Andrade, V.J. and Pereira, J.C.C. (1999): "Evaluation of four mathematical functions to describe scrotal circumference maturation in Nellora Bulls". Theriogenology, 52, pp. 2534.

Rege, J.E.O.; Toe, F.; Mukasa-Mugerwa, E.; Tembely, S.; Anindo, D.; Baker, R.L. and Lahlou-Kassi, A. (2000): "Reproductive characteristics of Ethiopian highland sheep II. Genetic parameters of semen characteristics and their relationships with testicular measurements in ram lambs". Small Rumin. Res. 37, pp. 173-187.

Salhab, S.A.; Zarkawi, M.; Wardeh, M.F.; Al-Masri, M.R. and Kassem, R. (2001): "Development of testicular dimensions and size, and their relationship to age, body weight and parental size in growing Awassi ram lambs. Small Rumin”. Res. 40, pp. 187-191.

Sönmez, R. and Kaymakçı, M. (1987): "Koyunlarda Döl Verimi”. Ege Üniv. Zir. Fak.Yay., No. 404.

Terawaki, Y.; Sueda, E.; Matuzaki, S.; Akami, Y. and Fukui, Y. (1994): "Relationships between testicular growth and body measurements in Holstein bulls". Nim. Sci. Techol., 65, pp. 1044-1055.

XLSTAT. (2015): "Program v. 7.5.2 for Windows", Addinsoft, 1995-2015.

Yllmaz, A. and Aygün, T. (2002): "Some testis characteristics in Norduz Male Lambs". University of Yüzüncü Yil, J Agric. Sci., 12(1), pp. 21-26.

Zeng, Y.H. and Lu, B.Q. (1987): "The development of sexual activity and semen production in ram lambs of the Hu breed of sheep". Chinese J. Anim. Sci., 3, pp. 5-8. 


\section{دراسة بعض قياسات الخصية وعلاقتها بوزن الجسم في ذكور الحملان الكرادية جومان علاء اللين عصر}

Email: choman.omer@univsul.edu.iq Assiut University web-site: www.aun.edu.eg

أجري هذا البحث لقياس تطور بعض صفات الخصية ودراسة مدى أرتباط هذه الصفات مع نمو الجسم في ذكور الحملان الكرادية

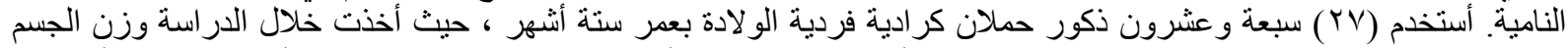

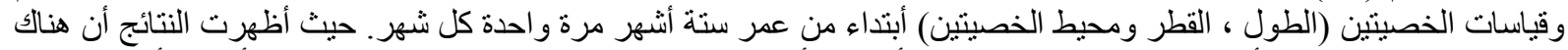

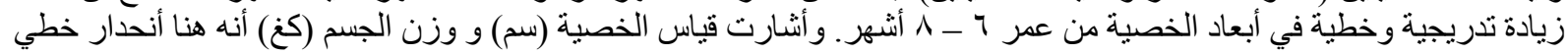

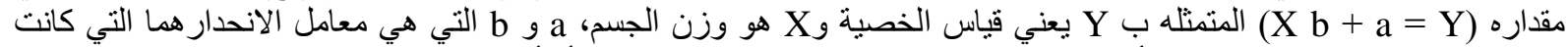

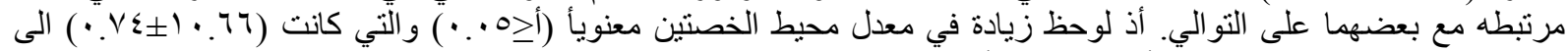

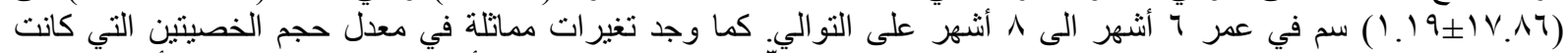

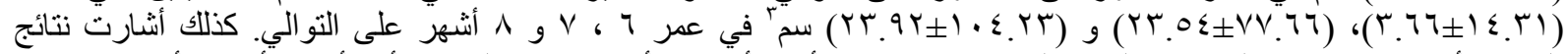

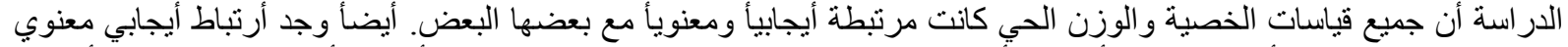

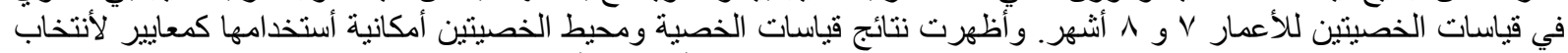

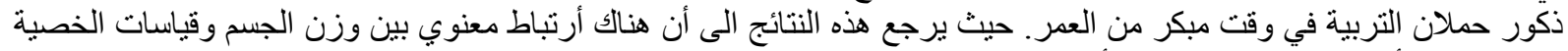

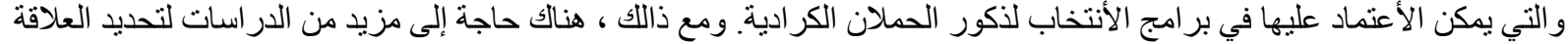
بين المعايير الثكلية للخصيتين و الخصوبة التي تحددها نو عية المني المنتج في الكبان الكر الكرادية.

الكلمات المفتاحية: نكور حملان كرادية ، نمو الخصيتين ، وزن الجسم ، محيط الخصيتين. 